\title{
Financial Autonomy in Vietnamese Public Health Service Units: A Study in Ho Chi Minh City
}

\author{
Nguyễn Trọng cơ ${ }^{1}$, Ngô Thanh Hoàng ${ }^{1}$, \& Hy Thị Hải Yến ${ }^{1}$ \\ ${ }^{1}$ Academy of Finance, Hanoi, Vietnam \\ Correspondence: Ngô Thanh Hoàng, Academy of Finance, Hanoi, Vietnam.
}

Received: August 20, 2021

Accepted: September 29, 2021

Online Published: October 19, 2021

doi:10.5539/ibr.v14n11p32

URL: https://doi.org/10.5539/ibr.v14n11p32

\begin{abstract}
In the renovation of the public non-business sector, the financial renovation is a particularly important content, which is a key condition for autonomous non-business units to improve the quality of public services as well as the efficiency of state budget spending. Renovating the financial mechanism of public non-business units has been identified as one of the breakthroughs of the Vietnam Finance Strategy until 2020 [Prime Minister, (2012)]. Implementing the financial autonomy mechanism has created the initiative for non-business units to manage financial expenditures effectively and mobilize the contribution of society for the development of non-business activities. In this process, public healthcare has been and will be an area focused in Vietnam and most provinces of Vietnam, including Ho Chi Minh City. Base on the theoretical framework for the autonomy mechanism, this article focuses on analyzing the actual situation of implementing the financial autonomy mechanism of the public health service units in Ho Chi Minh City, Vietnam for the period 2012-2018. Since then, it indicates the achieved results, limitations, causes, and some recommendations to promote the implementation of the financial autonomy mechanism of public health service units in the context of world economic integration.
\end{abstract}

Keywords: autonomy, finance, non-business units, public health, Vietnam

\section{Introduction}

The autonomy of public non - business units in Vietnam has been a key issue to reform the organization, the management system, and the improvement of the quality and effectiveness of them. It has had a great impact on more than 30,000 public non - business units in all sectors and nearly 4,000 public health service units in Vietnam. Otherwise, state budget expenditure for these entities has been decreasing, along with the renewal of the mode of allocation - instead of allocating directly to the public non - business units, the State give directly to the public service users. It has created many opportunities but also a big challenge for these units, lead them to changing their operation in order to take initiative in financial resources, to maintain and to develop revenue sources.

Ho Chi Minh City is the largest city in Vietnam, therefore, it faces many challenges in socio-economic development. The demand for the quality of public services is increasing in the context that the state budget allocated to operating expenses of public non-business units tends to decrease. The city has a per capita income of 6,537 million VND/person/month, ranking second in Vietnam after Binh Duong Province [Anh, D. (2021)]. Ho Chi Minh City is a locality capable of socializing non-budget financial resources in the development of the health sector and other fields. Therefore, in the city, many public non-business units are eligible to exercise financial autonomy. This is also an opportunity and a challenge for the management staff to renew their thinking and innovate management towards ensuring people's satisfaction in using public services. The implementation of the autonomy mechanism of medical public service units in Ho Chi Minh City has strengthened the autonomy and initiative of the unit heads in personnel management and financial management; created opportunities for units to control internal expenditures, promote democracy, initiative, and creativity of officials, public employees; improve management skills, quality of operations; publicity and transparency in the organization of work arrangement, personnel, and financial spending. Although there have been many efforts, there are still significant obstacles in the implementation of autonomy such as the legal framework on the autonomy mechanism for public hospitals is not yet complete; lack of regulations on investment in the form of public-private partnership, joint venture, association, on the use of high-tech medical equipment in public health facilities; there are still many constraints related to the apparatus, people, personnel arrangement and payroll.

Facing that situation, continuing to implement the financial autonomy mechanism of public health service units 
in Ho Chi Minh City in the context of world economic integration is a significant issue. Starting from the above practice, through researching to find out the answer to the research question: (i) How is the actual process of implementing the financial autonomy mechanism of public health service units in Ho Chi Minh City, (ii) What achievements have been made in this process and what limitations exist, (iii) What are the main reasons for these limitations, (iv) And How to promote the implementation of the financial autonomy mechanism in those units, the authors would like to share our views and propose some recommendations with a scientific and practical basis on this issue.

\section{Literature Review}

According to author Ausha Jackson [Jackson, A. (2016)], a non-profit business, also known as a not-for-profit organization, is a tax-exempt organization formed for religious, charitable, literary, artistic, scientific, or educational purposes. It is an incorporated business from which its shareholders or trustees do not benefit financially. Any money earned must be retained by the organization, and used for its expenses, operations, and programs. A few well-known non-profit organizations include Habitat for Humanity, Red Cross, and United Way. Public non-businesses are organizations established by competent State agencies, political, socio-political organizations by the law with legal status, providing public administration service, serving state management in fields such as education, training, healthcare, scientific research, culture, physical training, and sports, labor invalids and society, media and other non-business activities prescribed by law [Duong, N. (2021)].

The system of public non-business units with a large contingent of intellectuals, scientists, etc. has made great contributions to the cause of national construction and defense; contributed to the implementation of the goals of sustainable poverty reduction, social justice, and the completion of the Millennium Development Goals. Author Tuyet Le [Tuyet, L. (2020)] affirms that public non-business units play a key role in providing public non-business services and implementing social security policies. The degree of autonomy of public non-business units is divided into 4 types: Units that cover recurrent expenditures; The unit self-finances recurrent and investment expenses; The unit self-insured part of recurrent expenditure; The unit is guaranteed by the State for recurrent expenditure [Oanh, P. (2020)].

According to Yingyao Chen and Ke Xiong [Chen, Y. \& Xiong, K. (2017)] hospitals are classified into 4 types: budget units; autonomous units; private and cooperative units, and each type of hospital has a different degree of autonomy. The degree of autonomy is reflected in the following aspects: the right to decide; Market Access; the ultimate beneficiary; social responsibility and function. The implementation of granting financial autonomy to public non-business units has brought some positive results, such as public non-business units have actively used state budget allocations to carry out the implementation of the project. perform tasks effectively; at the same time, actively use assets and human resources to develop and improve the quantity and quality of public non-business service provision, thereby developing revenue [Nguyet, N. (2019)].

Author M.Ramesh [Ramesh, M. (2008)] states that the Singapore government started implementing reforms in public hospitals in the mid-1980s. The reform allowed public hospitals to be autonomous and forced them to compete with fees for medical examination and treatment services. At the same time, the reformation also makes patients pay more when using medical services. Research has shown that this reform has led to a rapid increase in the cost of medical services, rather than a decrease. Incentive mechanisms for increased revenue risk leading to "commercialization of the health system", patients will be subjected to increased revenue and may cause inequities in health care; increased cost burden for patients; redundancy designation; abuse of testing and abuse of expensive technical services that lead to limited access to health services of the people, especially the poor, the near-poor, those without health insurance cards and disadvantaged social groups [Ministry of Health, 2014].

Author Le Kien [Kien, L. (2019)] stated that the income disparity is due to the lack of incentives and attractive policies for health workers, especially those with high qualifications working in hospitals and medical facilities. poor area; There is a situation of labor shifting from remote areas to centers, from public hospitals to private hospitals. Therefore, to improve the quality of health care and social security services, the Government needs to strengthen state management; Review, evaluate, and perfect the legal system on public financial reform for public health service providers, joint ventures, partnerships, investments, socialization in the health sector and relevant policies to ensure consistency, transparency, suit the new situation and meet the development requirements of the public health system [Anh, N. (2020)].

According to author SuneetaSharmaa [Sharmaa, S. (2001)], in India's state-administered health care system, many government decision-makers are exploring the introduction or expansion of hospital autonomy as a means of improving the efficiency and financial sustainability of the overall public health care system. One initiative that has recently received a considerable amount of attention is the introduction of Medicare Relief Societies 
(MRS) in the state of Rajasthan. The societies are autonomous organizations that are formed to complement and supplement existing service provision in public hospitals. The state has provided incentives for the formation of MRS by relaxing state-imposed restrictions on the collection and use of revenue by hospitals, thus encouraging the use of alternative financing mechanisms such as user-fee schemes and in-hospital pharmacies. To get over the crisis, many healthcare facilities will have to reduce costs (e.g. lay off employees) or apply for a line of credit from a bank, schedule repayment from creditors, or get funding from shareholders. Companies that do not have enough assets to pay off their debts will go bankrupt, with the possible result of asset sales and complete cessation of operations. This is not just about small private clinics with little capital before COVID, public hospitals in OECD countries are already in a dire financial situation with oversized staffing, the general pattern is reduced capital investment and increased debt. In France, for example, the consolidated debt of public hospitals is already 30 billion euros [Meessen, B. \& Roodenbeke, E. (2020)]

From these studies above, we can see that they almost referred to the dual effects of implementing reforms in the public health sector on a national basis. Thus, with the study of the implementation of the financial autonomy mechanism in public non-business units in special provinces of the country like this article, it can open up new research directions to link research results with reality.

\section{Method}

The authors mainly use descriptive statistical methods, one of the most suitable methods to analyze the results and limit the implementation of the financial autonomy mechanism in public non-business units in Ho Chi Minh City, Vietnam. These methods help us to simplify large amounts of data sensibly with a long duration from 2012 - 2018. Secondary data sources collected at the Department of Finance of Ho Chi Minh City: Financial statements of public non-business units for the period of 2012 to 2018; Report on the situation and results of the implementation of the autonomy mechanism of public non-business units according to Decree 43/2006/ND-CP for the period 2012-2018. Data source provided at the Department of Health: report on the situation operating in hospitals (Department of Health); Ho Chi Minh City Statistical Yearbook 2019.

\section{The Implementation of Financial Autonomy Mechanism in Public Non-Business Units in Ho Chi Minh City, Vietnam}

\subsection{Socio-economic Overview of Ho Chi Minh City}

Ho Chi Minh City (also known as Saigon) formerly known as Saigon before 1975 or Saigon-Gia Dinh is the largest city in Vietnam in terms of population and the scale of urbanization. It is also the economic, political, cultural, and educational center of Vietnam. Ho Chi Minh City is a centrally run city belonging to a special urban category of Vietnam along with the capital Hanoi [Ministry of Planning and Investment (2018)]. Located in the transition zone between the Southeast and the Southwest, this city currently has 16 districts, one city, and five districts, with a total area of 2,061 square kilometers. The population as of April 2019 is 8,993,082 people and is also the place with the highest population density in Vietnam [Thao, H. (2019)].

Thanks to its natural conditions, Ho Chi Minh City becomes a transport hub of Vietnam and Southeast Asia, including road, rail, waterway, and air. In the fields of education, media, sports, and entertainment, Ho Chi Minh City all hold certain positions.

The goal by 2025, Ho Chi Minh City will be a smart city, a modern service-industrial city, maintaining the role of an economic "locomotive" and a growth engine of the key economic region. in the south and the whole country, leading in innovation, having a good quality of life, civilization, modernity, gratitude, GRDP per capita is about 8,500 to $9,000 \mathrm{USD} / \mathrm{year}$; Orientation to 2030 the city will be the center of economy, finance, trade, science - technology and culture of Southeast Asia [Liem, H. (2020)].

\subsection{Actual Situation of Implementing Financial Autonomy Mechanism in Public Health Service Units in Ho Chi} Minh City

4.2.1 Guidelines and Policies of Ho Chi Minh City in the Implementation of the Autonomy Mechanism in Public Health Service Units

The granting of financial autonomy to LSPs is currently being implemented by the city government by various central legal documents. Based on these documents, the city has issued guidelines and policies in the implementation of the autonomy mechanism at the VASC in different fields. Specifically:

On December 31, 2015, the City People's Committee issued Plan No. 8195/KH-UBND to implement the Prime Minister's Decision No. 695/QD-TTg dated May 21, 2015 promulgating the Prime Minister's Decision No. implementation plan of the Government's Decree No. 16/2015/ND-CP dated February 14, 2015 stipulating the 
autonomy mechanism of public non-business units.[ People's Committee of Ho Chi Minh City. (2015)].

On September 1, 2016, the City People's Committee issued Official Letter 4815/UBND-KT on building a list of public non-business services using the state budget under the local management according to Plan No. 8195/KHPeople's Committee dated December 31, 2015 of the City People's Committee.[ People's Committee of Ho Chi Minh City. (2015)]

The People's Committee of the city also issued Decision No. 6439/QD-UBND dated December 9, 2016 on the establishment of a Working Group to orient the development of activities of public non-business units in Ho Chi Minh City until 2021.[ People's Committee of Ho Chi Minh City. (2016)].

Decision No. 926/QD-UBND dated March 7, 2017 of the City People's Committee on the development orientation of the activities of the public service units until 2021. Next, on April 16, 2019 Action Program No. 33-CTrHD/TU of the City Party Committee implements Resolution No. 19-NQ/TW dated October 25, 2017 of the Party Central Committee on continuing to renovate the organizational and management system, improving the quality and efficiency operation results of public non-business units are issued; Decision No. 2659/QD-UBND dated June 24, 2019 of the City People's Committee promulgating the Implementation Plan of the Action Program on the implementation of Resolution No. 19-NQ/TW dated October 25, 2017 of the City People's Committee. The Sixth Conference of the 12th Centralization Executive Committee on continuing to renovate the organization and management system, improving the quality and performance of public non-business units.[ People's Committee of Ho Chi Minh City. (2017)].

4.2.2 The Implementation of Financial Autonomy Mechanism in Public Health Service Units in Ho Chi Minh City

a) Status of classification of public health service units in Ho Chi Minh City

From 2012 to 2018, public non-business units in the city have been assigned three times to decide on autonomy in the type of non-business units. After three times of awarding the decision to give autonomy to the units, from 2018 to 2020 shows the most obvious change in the type of public health service units.

Table 1. Classification of public health service units in Ho Chi Minh City in the period 2012-2018

\begin{tabular}{lccc}
\hline & $\begin{array}{c}\text { The unit self-finances all } \\
\text { recurrent operating expenses } \\
(\mathrm{n}=7)\end{array}$ & $\begin{array}{c}\text { The unit self-finances part of the } \\
\text { regular operating expenses } \\
(\mathrm{n}=7)\end{array}$ & $\begin{array}{c}\text { The unit is fully funded by the } \\
\text { state budget for regular } \\
\text { operations } \\
(\mathrm{n}=7)\end{array}$ \\
\hline 2012 & 6 & 28 & 10 \\
2013 & 6 & 32 & 7 \\
2014 & 6 & 33 & 8 \\
2015 & 7 & 31 & 8 \\
2016 & 7 & 31 & 9 \\
2017 & 8 & 29 & 4 \\
2018 & 29 & 12 & 8 \\
\hline
\end{tabular}

Source: Synthesized data from the report on the implementation of financial autonomy in Ho Chi Minh City in the period of 2012 to 2018.

Thus, in terms of the city block, if in 2012 in Ho Chi Minh City, there were only six hospitals that self-financed all recurrent expenses and 28 hospitals that self-financed part of recurrent expenses, then by 2017, the number of hospitals self-financed for recurrent expenses has increased to eight hospitals and in 2018 this number was 29 units.

b) The status of autonomy in revenue sources and levels at public non-business medical units in the city Ho Chi Minh

* Autonomy in the source of income:

In the structure of non-business revenues, to adapt to the process of financial autonomy, many public non-business units in the city have developed and expanded many types of services. In addition to developing on-demand medical examination and treatment services, many hospitals have expanded other ancillary services. The diversity in the structure of non-business revenues can be seen in Table 2 on the structure of revenue sources of non-business units in the city in the period 2012 - 2018. 
Table 2. Non-business revenue at municipal public health service units in Ho Chi Minh City in the period 2012-2018 Unit: million VND

\begin{tabular}{ccccc}
\hline & $\begin{array}{c}\text { Collection of medical } \\
\text { examination and treatment } \\
(\mathrm{n}=7)\end{array}$ & $\begin{array}{c}\text { Collection of medical } \\
\text { examination and treatment } \\
\text { upon request } \\
(\mathrm{n}=7)\end{array}$ & Other revenues & Total \\
\hline 2012 & $6,391,050$ & $1,220,650$ & $(\mathrm{n}=7)$ & 79,397 \\
2013 & $6,874,389$ & $1,756,048$ & 60,882 & $8,691,319$ \\
2014 & $7,088,002$ & $2,175,878$ & 74,112 & $9,337,992$ \\
2015 & $7,776,417$ & $2,512,853$ & 124,424 & $10,413,693$ \\
2016 & $9,417,782$ & $2,889,853$ & 276,83 & $12,584,465$ \\
2017 & $11,280,882$ & $2,980,715$ & 317,509 & $14,579,106$ \\
2018 & $11,421,569$ & $10,502,630$ & $367,481.4$ & $22,291,681$ \\
\hline
\end{tabular}

Source: Summary of autonomy reports of public healthcare entities in Ho Chi Minh City for the period 2012-2018

* Autonomy in terms of price's public services

Healthcare is a public sector that has a great impact on social security. Therefore, any adjustments in the level of revenue, especially the price of medical examination and treatment services, affect not only the operation of public non-business units but also the whole society. It can be seen that it is rare for a price to be governed by so many Law documents. The competence to decide on the price of medical examination and treatment services is currently related to 03 laws: Law on medical examination and treatment; Law on Health Insurance; Price law. Accordingly, the price of medical examination and treatment services covered by health insurance shall be regulated by the Minister of Health; the price of medical examination and treatment services without health insurance shall be decided by the People's Council of the province based on the price bracket promulgated by the Ministry of Health; price of medical examination and treatment services on request shall be set by the Minister of Health in a price bracket (currently decided by the Directors of the units while waiting for the Ministry of Health to issue the price bracket).

- Price structure of medical examination and treatment services

At present, the price structure of medical examination and treatment services covered by health insurance and without health insurance has not fully included the costs of formation, only including:

(1) Direct costs include:

(i) Expenses charges for drugs and supplies;

(ii) Expenses for electricity, water, and waste treatment;

(iii) Direct equipment maintenance and repair costs,

(2) Salaries and allowances according to the current base salary. The following factors have not been taken into account:

(i) Depreciation of fixed assets;

(ii) Training and scientific research expenses and

(iii) Management expenses.

This is a big challenge for hospitals when they are converted to the type of unit that ensures all regular operating expenses. Because when implementing the autonomy mechanism, in essence, hospitals need to collect all that the hospital has spent (only in terms of recurrent costs) so that the hospital can do it." financial autonomy". Although the roadmap for calculating full price in the future will be towards calculating depreciation expenses, at present, to adapt to the autonomy mechanism, hospitals have to borrow to invest in medical equipment for operation. Although they do not have to pay interest because they are supported by the state budget, the loan principal is currently struggling to find sources to pay because the amortization cost has not been included in the price.

For on-demand medical examination and treatment, the circular guiding the setting of prices for health care services, medical examination, and treatment on demand at public medical facilities are still being developed by the Ministry of Health. Therefore, at present, the price of medical examination and treatment services is on-demand at public hospitals in the city. Ho Chi Minh City is decided by the directors of the hospitals. However, according to actual research, hospitals currently do not have a process to set prices for medical examination and 
treatment services is on-demand in terms of price structure and, in particular, there is no basis for statistical cost formation. Prices for medical services on request. Therefore, it is difficult to explain the price of medical examination and treatment services is on-demand, especially the price of the requested hospital bed.

- Process for promulgating prices for medical examination and treatment services

Currently, the price of medical examination and treatment services without health insurance is promulgated by the Minister of Health based on the price of medical examination and treatment services covered by health insurance, then each province must submit to the People's Council. people decide. To approve the People's Council, the City Health Department in Ho Chi Minh City has to build a price structure, assess the impact, and consult the Statistics Department, the Department of Finance, the Fatherland Front, and the Department of Justice, but in the end, still collect the maximum price of the Circular prescribed by the Minister of Health...

Table 3. Documents on the price of health insurance and non-insured services of the Government of Vietnam

\begin{tabular}{lccc}
\hline & $\begin{array}{c}\text { Time of } \\
\text { application }\end{array}$ & $\begin{array}{c}\text { Price of health care services } \\
\text { with health insurance }\end{array}$ & $\begin{array}{c}\text { Price of medical services } \\
\text { without health insurance }\end{array}$ \\
\hline Circular 37/2015/TTLT-BYT-BTC & $01 / 03 / 2016$ & $\mathrm{x}$ & $\mathrm{x}$ \\
Circular 02/2017/TT-BYT & $01 / 06 / 2017$ & & $\mathrm{x}$ \\
Circular 44/2017/TT-BYT & $01 / 01 / 2018$ & & $\mathrm{x}$ \\
Resolution 06/2017/NQ-HĐND & $01 / 08 / 2017$ & $\mathrm{x}$ & \\
Circular 15/2018/TT-BYT & $15 / 07 / 2018$ & $\mathrm{x}$ & $\mathrm{x}$ \\
Circular 39/2018/TT-BYT & $15 / 01 / 2019$ & & $\mathrm{x}$ \\
Circular 13/2019/TT-BYT & $20 / 08 / 2019$ & & $\mathrm{x}$ \\
Circular 37/2018/TT-BYT & $15 / 01 / 2019$ & & \\
Circular 14/2019/TT-BYT & $20 / 08 / 2019$ & & \\
Resolution 15/2019/NQ-HĐND & $01 / 01 / 2020$ & & \\
\hline
\end{tabular}

Source: Compiled by the author

As evidenced in Table 3, it can be seen that the time delay, as well as the complexity in the process of formulating and issuing the price of medical examination and treatment services without health insurance, have not brought benefits to the medical institutions. local health authorities in general, the Department of Health of Ho Chi Minh City in particular, and public health facilities. Therefore, it is necessary to bring the service price between medical examination and treatment with health insurance and medical examination and treatment without health insurance to the same level to avoid the existence of two medical examination and treatment prices in a medical facility, causing difficulties in price management, software development, payment and explanation to patients.

c) Actual situation of autonomy in expenditure and expenses at public non-business units in the city Ho Chi Minh

From 2012 to 2017 , salary costs in the units accounted for about $22 \%$, public service payments accounted for a small proportion of $2.1 \%$ and the highest proportion was industrial expenses. professional services reached around $70 \%$ (Table 4).

Entering 2018, with a series of changes from the type of autonomous non-business units, to the change in administrative and non-business accounting according to Circular 107/2017/TT-BTC replacing Decision 19/2006/ QD-BTC, expenses and expenses have been more separated. Although there is a division into 4 groups as guided by Circular 107: (1) Cost of salaries, wages, and other expenses for employees, (2) Cost of materials, tools, and services already paid. use, (3) Depreciation of fixed assets, (4) Other operating expenses. 
Table 4. Cost of medical examination and treatment at Ho Chi Minh City's hospitals in the period 2012 - 2018 Unit:\%

\begin{tabular}{lccccc}
\hline & $\begin{array}{c}\text { Expenditures on } \\
\text { people (salaries, } \\
\text { allowances, social } \\
\text { insurance, health } \\
\text { insurance) } \\
\text { (n=7) }\end{array}$ & Professional expenses & $\begin{array}{c}\text { Public services } \\
\text { (electricity, } \\
\text { water, stationery, } \\
\text { fuel, expenses } \\
(\mathrm{n}=7)\end{array}$ & $\begin{array}{c}\text { Other } \\
\text { expenses }\end{array}$ & Total \\
\hline 2012 & 21.05 & 71.68 & 2.28 & 4.99 & 100 \\
2013 & 22.26 & 70.96 & 2.24 & 4.54 & 100 \\
2014 & 23.51 & 69.6 & 2.29 & 4.6 & 100 \\
2015 & 22.77 & 70.5 & 2.28 & 4.46 & 100 \\
2016 & 21.65 & 71.73 & 2.11 & 4.51 & 100 \\
2017 & 21.61 & 71.85 & 2.08 & 4.46 & 100 \\
2018 & 17.74 & 63.05 & 5.25 & 13.95 & 100 \\
\hline
\end{tabular}

Source: Summary of financial reports of hospitals in Ho Chi Minh City for the period 2012-2018

Table 4 shows that the operation of public non-business units in the whole period from 2012 to 2018 is still mainly based on professional expenses, which is specific to the health-quality sector. The number of medical staff plays a more important role. Therefore, with the current average salary payment coefficient and such actual cost structure, it is not suitable with the characteristics of the health sector.

d) The status of autonomy in the distribution of results in public health service units in Ho Chi Minh City

* Regarding the payment of additional incomes of officials, public employees, and workers in public health service units

One of the goals of the autonomy mechanism is to increase the income of officials and employees in public non-business units. If given autonomy and self-responsibility "right" with the "absorption" ability of the unit, this goal can be achieved. Average income data of officials and employees of municipal hospitals in Ho Chi Minh City can attest to this statement.

Table 5. The average income of officials and employees of hospitals in Ho Chi Minh City in the period 2012-2018 Unit: VND

\begin{tabular}{cc}
\hline & $\begin{array}{c}\text { Average income/month } \\
(\mathrm{n}=7)\end{array}$ \\
\hline 2012 & $7,930,734$ \\
2013 & $7,951,487$ \\
2014 & $8,232,790$ \\
2015 & $7,884,434$ \\
2016 & $7,937,906$ \\
2017 & $8,759,463$ \\
\hline
\end{tabular}

Source: Summary of financial reports of hospitals in Ho Chi Minh City for the period 2012-2018

Table 5 shows that in the period 2012 - 2018, the average income (including additional income) of staff at hospitals increased steadily, 1.05 times more in 2017 compared to 2012. $2012-2017$ is the period with little change in the classification of the unit type. However, by 2018, the average income of officers and employees at the units decreased to about $87,68 \%$ compared to the average income in 2017 . This shows arising from the great change in the classification of types of autonomous units in the period of $2018-2020$ - from eight units to 29 units self-financed for regular operation. Specifically, out of these, there are 11 units with a decrease in additional income, the highest is $64 \%$ and the lowest is $5 \%$.

In 2018, some hospitals did not have the "ready" parallel to the "absorption capacity" corresponding to the type of unit that self-financed regular operating expenses. Therefore, when the state budget is completely non-funded, these hospitals have to bear all the regular expenses of the hospital, and accordingly, the difference in revenue expenditure from regular activities in 2018. decreased, and led to the additional income of officers and employees 
in this year also decreased. Thus, the "difficulty" of the hospitals here is that to retain doctors, they must have a good remuneration and income regime - but if the hospital "pays for itself", the hospitals cannot afford it. power.

* Situation of setting up and using funds

Since Thanh Pho promoted the assignment of financial autonomy to public non-business units, the number of funds set up has increased significantly, more than 3 times in 2018 compared to 2012. In which, the development fund Non-business activities still account for the highest proportion compared to the other two funds, about 60-63\% of the total fund set-up (table 6).

Table 6. The situation of setting up and using funds of public health care providers in Ho Chi Minh City Unit: million VND

\begin{tabular}{cccc}
\hline & $\begin{array}{c}\text { Foundation for career development } \\
(\mathrm{n}=7)\end{array}$ & $\begin{array}{c}\text { Bonus and welfare } \\
(\mathrm{n}=7)\end{array}$ & $\begin{array}{c}\text { Income stabilization reserve fund } \\
(\mathrm{n}=7)\end{array}$ \\
\hline 2012 & 425,587 & 233,193 & 30,963 \\
2013 & 480,945 & 315,294 & 2,765 \\
2014 & 587,495 & 353,922 & 13,400 \\
2015 & 730,938 & 388,062 & 127,215 \\
2016 & $1,143,184$ & 540,329 & 47,676 \\
2017 & $1,294,644$ & 606,675 & 105,974 \\
2018 & $1,308,789$ & 712,583 & 222,476 \\
\hline
\end{tabular}

Source: Summary of autonomy reports of public healthcare entities in Ho Chi Minh City for the period 2012-2018

\section{e) Actual situation of planning and arrangement of units}

* About the network of public health service units in the city. Ho Chi Minh

According to data from the City Statistics Office. In Ho Chi Minh City, the distribution of health facilities varies between regions and there is a relatively large difference between districts. While the total number of medical facilities in Binh Tan district is only 16, with the rate of 48,232 people/medical facility, in District 5, with a large number of medical facilities, the population/health facility ratio is only 4,708, 10 times lower than that of Binh Tan district. In addition, there are areas where the number of hospitals accounts for a large proportion (over $60 \%$ as in District 1) in the total number of medical facilities, but there are also areas where the number of hospitals accounts for only 5-6\% (as in District 11). This leads to an imbalance of medical resources in areas of the city [Ho Chi Minh City Bureau of Statistics. (2019)].

* About organization and arrangement of public health service units in Ho Chi Minh City

Over the past time, especially in 2018, the health sector in Ho Chi Minh City has had many adjustments, organization, and rearrangement of medical non-business units in the area. First of all, the project to reorganize the 'District Medical Center and Hospital under the People's Committee of the district' into a 'District Health Center under the Department of Health of Ho Chi Minh City' " Accordingly, uniformly implement the model that each district level has only one multi-functional medical center (except for districts with hospitals of grade II or higher), including preventive medicine, population, medical examination and treatment, rehabilitation and other medical services, followed by a project to reorganize preventive medicine units into Centers for Disease Control based on merging organizations and units have the same functions, tasks, and integrated activities.

\section{g) Actual situation of developing and implementing internal spending regulations}

Through studying some internal spending regulations in hospitals in the city. In Ho Chi Minh City, it can be seen that there are basic similarities in the structure and content of the regulations. Specifically, the regulation includes the following sections:

- Regulations on funding sources for operation at the unit, including regulations on the content of non-business revenues; regulations on exemption and reduction of hospital fees; regulations on anti-lost collection of hospital fees and regulations on management of revenues at the unit. In particular, all revenues generated at the hospital are made by the cashier department of the Finance - Accounting Department, updated and reported on a timely basis.

- Regulations on expenditures and management of expenditures in the unit. Including regulations on the content and level of spending for people, administrative expenses, professional expenses, regulations on procurement, management, and use of assets at the unit. Most of these contents are all built based on legal documents on spending norms of the State, the City People's Committee, and guidance from the City Health Department. 
Particularly for business and service activities in the unit (in the regulations are understood as on-demand medical examination and treatment activities and ancillary services), the hospital's internal spending regulations set out the following contents: Cost content related to service activities, the maximum cost level for each content, including directly incurred costs, overtime income of direct-indirect departments, outsourced labor costs, depreciation expense for machinery and equipment serving production, business activities, and service provision, advertising, marketing, commission, and tax payment.

- Regulations on the distribution of revenue and expenditure difference at the unit. First of all, the hospital is responsible for ensuring the basic salary according to the ranks, grades, positions, and the minimum salary prescribed by the state for employees. Based on the total revenue and actual total expenditure, the difference between revenues and expenditures is used to set up the funds of the entity and to set aside the additional income fund and the provision for income stabilization in the corresponding proportions with regulations on the type of non-business unit that the unit applies. The distribution and use of the additional income fund shall comply with the Regulation on internal expenditure on emulation classification and the level of expenditure based on the division coefficient by position.

\subsection{General Assessment of the Implementation of Financial Autonomy Mechanism of Public Health Service Units in Ho Chi Minh City, Vietnam}

\subsubsection{Results Achieved}

One is, Regarding the implementation of the autonomy mechanism in performing tasks, organizational apparatus, and personnel in the public non-business health care units in Ho Chi Minh City - The units have taken the initiative to implement many solutions to develop expertise and techniques, sending staff to study at home and abroad to receive and apply techniques, especially new and high-tech techniques to develop and expand medical services to optimize the unit's operations, thereby maintaining and developing revenue, proactively balancing financial resources.

- Allowing units to self-manage all operating expenses to decide on the number of employees has facilitated the units to decide and recruit high-quality human resources to meet human resource needs. to serve the activities with increasing quality. The units have organized and rearranged personnel based on developing and completing the project of employment positions. Accordingly, personnel is arranged more scientifically, one person can do many things; step by step ensures the assignment of the right people, the right jobs, the right forte, promote the dynamism and creativity of the staff, contributing to the completion of the unit's professional tasks.

- Many units have signed work contracts for jobs that are not necessary to arrange for staff, such as cleaning, security, garden care, etc. Some units have also actively signed contracts. cooperate with domestic and foreign experts to participate in professional activities. As a result, the service quality, role, and reputation of the unit are enhanced.

Secondly, Regarding the implementation of the financial autonomy mechanism at the public non-business medical units in Ho Chi Minh City.

- In addition to the collection and strict management of revenue to avoid loss, the units have also regularly revised, supplemented, and perfected their internal spending regulations to serve as a basis for conducting audits. Control expenses and expenses of your unit. At the same time, in the process of operation, saving expenses and costs and balancing and adjusting the structure of expenditures and expenses is also the way that the units have deployed to balance revenue - expenditure in the year. autonomous process.

- Thanks to the increase in revenue, the savings in income-expenditure of employees in some units have been improved and tended to increase compared to before self-employment. Since then, creating an incentive mechanism for all individuals in the unit to participate in the self-control process, improving the operational efficiency of the unit.

- The units also actively recorded revenue in detail and recorded expenses according to the guidance of the administrative and non-business accounting regime according to Circular 107/2017/TT-BTC.

- In addition to optimally using resources from the development fund for non-business activities, many units have actively borrowed capital, implemented joint ventures, partnerships, or public-private partnerships to expand their scale and develop infrastructure. floor, equipment, and assets of the entity. Thereby, creating conditions for people to access advanced and modern public services, contributing to increasing revenue for the unit. 
- Regulations on internal expenditures at the units have been developed, improved, and supplemented regularly, partly meeting the financial management needs of the units. This is also the basis for the unit to control revenues, expenditures, spending norms, and distribution of results.

\subsubsection{Some Limitations}

Firstly, regarding the implementation of the mechanism of autonomy in performing tasks, organizational apparatus, and personnel in public health care units in Ho Chi Minh City.

- The regulations on the establishment and dissolution of organizations constituting public non-business units are not clear, so many problems are surrounding them. If the units are allowed to self-establish and dissolve, it may lead to the dissolution of faculties and departments with no revenue or low revenue, and the development of faculties and departments with revenue sources. While the implementation of activities according to the functions and tasks assigned by the State to ensure the provision of public services and ensure social security, is required to be carried out synchronously among the departments in the unit.

- Although they are autonomous in terms of personnel, the leaders themselves face many difficulties in downsizing the staff for inefficient employees. In addition, according to regulations, the source of payment of severance allowance is taken from the financial source of the unit, but some services do not include this allowance in the price of public services provided, so the units are currently having difficulty paying for this.

- The fact that the head of a public non-business unit is a civil servant, therefore, he cannot concurrently act as the leader of an investment establishment in the form of a public-private partnership (PPP), so this is also a limitation on the implementation of social policies. modernization, public-private combination to reduce load and improve service quality.

Secondly, Regarding the implementation of the financial autonomy mechanism at the public non-business medical units in Ho Chi Minh City.

- The classification of public non-business units is not suitable with the absorptive capacity of the units. From the analysis of the situation, it has been shown that some units have difficulty when being pushed to a higher type of autonomous unit. Specifically, when some units are self-sufficient in recurrent operating expenses when the state budget no longer provides funding, these units have not been able to actively compensate, leading to a reduction in the difference between revenues and expenditures for regular operations. and thereby leading to a decrease in additional income and fund set up.

- The economic - technical norms of each type of public non-business service have not been completed. To implement the method of ordering and bidding for public administrative services, it is necessary to have economic and technical norms as a basis for formulating public administrative service prices using state budget funds. However, in the city of Ho Chi Minh City and many other localities across the country, this content is still one of the biggest problems in the process of implementing the autonomy mechanism in public non-business units. In most of the fields in the city, even though there are norms from the central government in some areas, they have not been concretized and implemented.

-The process of implementing autonomy in revenue sources, the level of revenue at public career units is still inadequate. Many units have not actively taken advantage of their available resources to expand activities to exploit revenue sources for their units. For the health sector, the failure to fully calculate the cost structure in the price of medical examination and treatment services covered by health insurance and limitations in the regulations on prices for medical examination and treatment services covered by health insurance are generally applicable throughout the country. The specific distinction in each type of hospital and the specificity of each locality has led to a significant disparity between the implementation of autonomy in specialized hospitals and general hospitals, and also created difficulty for small-scale general hospitals. Therefore, the early implementation of the roadmap to adjust the price of public administrative services is essential for the units to be able to exercise financial autonomy.

- The management of expenditures and expenses in public non-business units has not been focused on. With the new development trend in medical public service units towards the goal of a "smart" city, a center for science and high technology application, it is only necessary to focus on "spending on people" or just focusing on "expenses of expertise" are not able to respond to the development trend. Regarding cost management, although in the process of self-control, the units have paid more attention to controlling and saving costs. However, detailed information on the actual cost items incurred in the units has not been reflected in a timely and complete manner, not associated with the method of cost classification in the price structure of public and non-business services. cost classification when setting norms, leading to difficulties in actively balancing financial resources. 
- Regarding the development and application of internal spending regulations within the public non-business medical units in the city. The internal spending regulation has so far promoted its role in internal financial management in public non-business units. However, although it has been completed and supplemented promptly, with the requirements that the financial autonomy mechanism sets for financial management at the units, the current role of the regulation Internal spending has just stopped as its name implies - "spending regulation". Most of the internal spending regulations in the units do not cover all revenue sources in all activities of the unit, but only focus on exploiting non-business revenue sources, there are no detailed regulations on the mechanism to control the revenue-increasing parts by regulations to avoid over-collection. The new spending norms stop at the level of setting norms and spending standards but have not yet developed technical and economic norms, there is no common standard on the cost structure for each service group, and the cost structure. cost of each part. In addition, in terms of distribution of results, currently only stopping at the distribution according to the prescribed rate, not paying attention to the use and method of using this distribution to reinvest in the development of the business. taste.

\subsubsection{The Causes of the Limitations}

\section{Objective reasons}

Firstly, the assignment of autonomy along with self-responsibility is not associated with the appropriate level and absorption capacity of the units. This leads to some units that have been raised to a higher degree of autonomy facing many difficulties.

Second, many mechanisms and policies are still slow to promulgate or promulgate incompletely, synchronously, and not keeping up with the development situation. Some policies are prerequisites and important conditions for granting autonomy to public non-business units, but they are slow to be promulgated, amended, and supplemented.

- Although Decree 16/2015/ND-CP was born and applied in 2016, up to now, many non-business areas without a guiding decree still comply with Decree 43/2006/ND-CP. And soon, the promulgation of a Decree to replace Decree 16 will also create many changes in mechanisms and policies, and the need to improve policies for each newly issued field will also be inevitable.

- Because there are no specific and clear criteria in demarcating public administrative services using and not using the state budget, it has led to some public non-business fields in the locality that do not have documents specifying the list of services use of state budget. This also leads to the lack of clear grounds to determine the investment method from the state budget according to Decree 32/2019/ND-CP - when to assign tasks, when to order and when to bid.

- The system of economic and technical norms as the basis for building and determining the price of public administrative services using the state budget has not been completed in many areas from central agencies, leading to localities such as Ho Chi Minh City. Ho Chi Minh also has no basis for the issue. This is also the cause of difficulties in determining unit prices as well as implementing state budget allocation according to the mechanism of ordering, assigning tasks, and bidding in association with the quantity and quality of public products and services.

Third, mechanisms and policies on joint ventures or public-private cooperation in public non-business units are still incomplete. In particular, the mechanism and policy in the use of public assets at public non-business units to participate in joint ventures, associations or public-private cooperation are still unclear, making investors uncertain. Is the cash flow profitable or not? In addition, investment firms are limited, have not diversified investment types in public non-business fields, and have not mobilized many resources of the society, thus partly slowing down the speed of investment. develop and modernize the public non-business sector in the city.

\section{Subjective reasons}

- First of all, the ability to absorb autonomy and self-responsibility in public non-business units is not uniform and suitable for the type of autonomous unit assigned. Some units are not ready and do not have a plan and plan to adapt to the autonomy roadmap. This creates a shortfall when the growth in non-business revenue cannot keep up with the decrease due to the lack of compensation from the state budget.

- The current way of managing and administering operations in general and financial management at the units has not met the requirements and challenges posed by the autonomy mechanism. Some units have not made full use of their input resources to optimize revenue. 
- The staff at the unit only focuses on the main activities, there is no qualified personnel in marketing and business administration. Accounting personnel has not been able to adapt to the new requirements in accounting work at the unit, which is management and financial analysis.

- The application of technology in management is still limited, lacks synchronization, requires large resources to invest in technology and information technology infrastructure. Therefore, it has caused many difficulties in management, reduced operational efficiency, and at the same time also caused difficulties in management, monitoring, and balance of capital.

\section{Recommendations on Some Solutions to Promote the Implementation of Financial Autonomy Mechanism of Public Health Service Units Ho Chi Minh City, Vietnam}

\subsection{For the Ministry of Finance and Central Agencies}

- Research and innovate the current method of making state budget estimates based on inputs to making state budget estimates based on output results. State budget management according to output results will be a tool for the State to focus public resources on activities that bring the most benefits to society, help improve public financial policies and contribute to enhancing efficiency. management of state budget expenditure.

- Request the Ministry of Finance to issue sufficient scientific and feasible norms for the management of budget expenditures.

- The Government should uniformly manage the promulgation of standards and norms, including norms promulgated by the Ministry of Finance; norms are set by the Ministry of Finance and assigned to the Provincial People's Council to decide specifically to suit local characteristics. Develop a framework of budget expenditure norms with different coefficients to suit the characteristics and budgetary capacity of each level of government; suitable to the characteristics and geographical conditions of each region; consistent with the size and specific characteristics of the state management agency. Apply job-based spending norms instead of the current payroll-based spending norms. To promulgate a standard system of equipment and working facilities suitable for each type of civil servant and public employee title for uniform application in state agencies. Based on a system of standards and norms, the agency or unit is entitled to make adjustments during the implementation process, by the work requirements and budget capacity of the unit.

\subsection{For Agencies and Departments in Ho Chi Minh City}

- The City People's Committee needs to study and submit to the City People's Council to adjust the system of budget allocation norms to ensure a scientific and appropriate calculation; promulgate spending norms within the central regulatory framework under the local authority to ensure that expenditure norms are close to reality and suitable to the local financial capacity to help budget-using units implement their tasks. favorable to achieve the province's economic and social development goals.

- Continue to review and improve revenue collection mechanisms and policies in the direction of both encouraging production development and mobilizing revenue sources, focusing on preventing revenue loss, striving to complete at the highest level the revenue estimate to create a budget source. funds for operating expenses of the entity.

\subsection{Solutions for Public Health Service Units in Ho Chi Minh City}

With the ultimate goal of developing public health service units and harmoniously solving the problem of needs and resources, public health service units in the city are forced to transform their methods of health care. its activities. In the immediate period, it is self-guaranteed for all recurrent expenditures, moving towards self-guaranteed recurrent and investment expenditures. To be able to convert to this type of unit, units must have a specific plan and roadmap to implement:

- Need to strengthen management, limit revenue loss; strictly control expenditures in the spirit of thrift, efficiency, and quality;

- Actively expand public non-business services as required to meet the needs of service users;

- Actively seek external investment sources to expand the scale, develop facilities, technical infrastructure, and modern technical equipment systems through forms such as public-private partnership, joint venture. link...

- To clearly define the State ownership capital in the units, have a method to preserve and develop this capital. At the same time, strictly implement the principle of not-for-profit activities.

- Develop an autonomy plan associated with the conditions, capabilities, and development strategy of the unit. 
- It is necessary to identify the financial advantages and difficulties of the unit when exercising autonomy, propose specific plans, roadmaps, and steps to remove each difficulty and problem based on consultation and with the support and consensus of all three parties: public health service units, financial management agencies, and local authorities.

- Replacing the current internal spending regulations of the unit with the development and promulgation of the unit's operating regulations is a breakthrough solution to help units get closer to the way they organize and manage their units. Tastes like a business model.

-Strengthen the application of information technology in accounting and financial management activities at the unit. Most of the public non-business units in Ho Chi Minh City currently have not yet implemented management accounting, while if the unit reaches the level of complete autonomy in both recurrent expenditure and investment, the role of management accounting is very important. Management accounting provides information for managers to make effective financial management decisions.

\section{Conclusion}

Through analyzing the actual situation of implementing the financial autonomy mechanism of the public health service units in Ho Chi Minh City, Vietnam for the period 2012-2018, it can be seen that most of the units have already achieved new developments from the benefits of the autonomy mechanism. However, besides that, there are still many limitations due to subjective and objective reasons. Realizing the reality, synchronously deploying solutions to the Ministry of Finance and central agencies, to agencies and departments, to public health service units in Ho Chi Minh City will contribute to effectively promoting the implementation of the financial autonomy mechanism of public non-business units in this city in the process of international economic integration...

\section{References}

Anh, D. (2021). Revealing 10 provinces and cities with the highest per capita income in 2020. Retrieved from https://vtv.vn/kinh-te/lo-dien-10-tinh-thanh-co-thu-nhap-binh-quan-dau-nguoi-cao-nhat-nam-2020-2021052 2112021557.htm

Anh, N. (2020). Some solutions to strengthen the implementation of the autonomy mechanism for public hospitals. Retrieved from

https://www.quanlynhanuoc.vn/2020/05/19/mot-so-giai-phap-tang-cuong-thuc-hien-co-che-tu-chu-doi-voibenh-vien-cong-lap/

Chen, Y., \& Xiong, K. (2017). Public Hospital Reform in China: Review and Outlook. Retrieved from https://www.researchgate.net/profile/Madhurimaundy/publication/319006619_Health_Service_Systems_in_ Transition_Challenges_in_India_and_China/links/598aa6eb0f7e9b9d44ca4be5/Health-Service-Systems-inTransition-Challenges-in-India-and-China.pdf\#page $=80$

Duong, N. (2021). What is a public service unit? What are public non-business units? Retrieved from https://luatduonggia.vn/don-vi-su-nghiep-cong-lap-la-gi-don-vi-su-nghiep-cong-lap-la-nhung-don-vi-nao/

Ho Chi Minh City Bureau of Statistics. (2019). Statistical Yearbook 2019. Retrieved from http://www.pso.hochiminhcity.gov.vn/web/guest/niengiamthongke2019

Jackson, A. (2016). What Is a Non-Profit Business? - Definition \& Example Business Plan. Retrieved from https://study.com/academy/lesson/what-is-a-non-profit-business-definition-example-business-plan.html

Kien, L. (2019). Autonomy of public hospitals: Better quality, but too much for patients. Retrieved from https://tuoitre.vn/tu-chu-benh-vien-cong-chat-luong-tot-hon-nhung-lam-thu-cua-nguoi-benh-201910030949 26742.htm

Liem, H. (2020). Efforts to maintain the position of economic locomotive of the whole country. Retrieved from https://nhandan.vn/tin-tuc-kinh-te/no-luc-giu-vung-vi-the-dau-tau-kinh-te-cua-ca-nuoc-620445/

Meessen, B., \& Roodenbeke, E. (2020). Financing the existence of autonomous hospitals (Yes, another lesson from COVID-19). Retrieved from https://p4h.world/en/who-ihf-financing-hospital-autonomy-covid19

Ministry of Health. (2014). Hospital autonomy: successes, difficulties, inadequacies and lessons learned. Retrieved from https://healthvietnam.vn/thu-vien/tai-lieu-tieng-viet/benh-vien/tu-chu-benh-vien-nhung-thanh-cong-kho-kha n-bat-cap-va-bai-hoc-kinh-nghiem

Ministry of Planning and Investment (2018). Socio-economic situation in December and 2018 of Ho Chi Minh City. Retrieved from http://www.mpi.gov.vn/Pages/tinbai.aspx?idTin=42163\&idcm=224 
Nguyet, N. (2019). Financial autonomy mechanism of public non-business units. Retrieved from https://www.tapchicongthuong.vn/bai-viet/co-che-tu-chu-tai-chinh-cua-nhung-don-vi-su-nghiep-cong-lap-6 0970.htm

Oanh, P. (2020). What is a public service unit? Retrieved from https://luathoangphi.vn/don-vi-su-nghiep-cong-lap-la-gi/\#: :text=\%E2\%80\%93\%20M\%E1\%BB\%A5c\%20\%C4 $\% 91 \% \mathrm{C} 3 \% \mathrm{ADch} \% 20 \% \mathrm{C} 4 \% 91 \% \mathrm{C} 6 \% \mathrm{~A} 1 \mathrm{n} \% 20 \mathrm{v} \% \mathrm{E} 1 \% \mathrm{BB} \% 8 \mathrm{~B} \% 20 \mathrm{~s} \% \mathrm{E} 1 \% \mathrm{BB} \% \mathrm{~B} 1$,quan\%20t\%C3\%A2m\%2 0\%С4\%91\%Е1\%BB\%83\%20\%C4\%91\%E1\%BA\%A7u\%20t\%C6\%B0

People's Committee of Ho Chi Minh City. (2015). Official Letter 4815/UBND-KT on building a list of public non-business services using state budget under local management according to Plan No. 8195/KH-UBND dated December 31, 2015 of the City People's Committee.

People's Committee of Ho Chi Minh City. (2015). Plan No. 8195/KH-UBND to implement the Prime Minister's Decision No. 695/QD-TTg dated May 21, 2015 promulgating the Implementation Plan of Decree No. 16/2015/ND-CP dated May 21, 2015. 14/02/2015 of the Government stipulating the autonomy mechanism of public non-business units.

People's Committee of Ho Chi Minh City. (2016). Decision No. 6439/QD-UBND dated December 9, 2016 on the establishment of a Working Group to orient the development of activities of public non-business units in Ho Chi Minh City until 2021.

People's Committee of Ho Chi Minh City. (2017). Decision No. 2659/QD-UBND dated June 24, 2019 of the City People's Committee promulgating the Implementation Plan of the Action Program on the implementation of Resolution No. 19-NQ/TW dated October 25, 2017 of the City People's Committee. The Sixth Conference of the 12th Centralization Executive Committee on continuing to renovate the organization and management system, improving the quality and performance of public non-business units.

People's Committee of Ho Chi Minh City. (2017). Decision No. 926/QD-UBND dated March 7, 2017 of the City People's Committee on the development orientation of the activities of the public service units until 2021.

Ramesh, M. (2008). Autonomy and Control in Public Hospital Reforms in Singapore. https://doi.org/10.1177/0275074007301041

Sharmaa, S. (2001). Developing financial autonomy in public hospitals in India: Rajasthan's model. https://doi.org/10.1016/S0168-8510(00)00106-8

Thao, H. (2019). As of 0:00 on April 1, 2019: The population of Ho Chi Minh City reached 8,993,082 people. Retrieved from https://hcmcpv.org.vn/tin-tuc/tinh-den-0-gio-ngay-1-4-2019-dan-so-tphem-dat-8-993-082-nguoi-149185862 1

Tuyet, L. (2020). Improve governance capacity of public non-business units. Retrieved from https://tapchitaichinh.vn/co-che-chinh-sach/nang-cao-nang-luc-quan-tri-cua-cac-don-vi-su-nghiep-cong-lap329114.html

\section{Copyrights}

Copyright for this article is retained by the author(s), with first publication rights granted to the journal.

This is an open-access article distributed under the terms and conditions of the Creative Commons Attribution license (http://creativecommons.org/licenses/by/4.0/). 